\title{
PENGGUNAAN MODEL TEAMS GAMES TOURNAMENT DENGAN TEKNIK FAMILI 100 TERHADAP MINAT BELAJAR FISIKA
}

\author{
Wahyuni, Nuryamin, Ali Umar Dani
}

Pendidikan Fisika Fakultas Tarbiyah dan Keguruan UIN Alauddin Makassar, wahyunisaleh171995@gmail.com

\begin{abstract}
Abstrak
Tujuan Penelitian ini adalah untuk mengetahui apakah model pembelajaran Kooperatif Tipe Teams Games Tournament (TGT) dengan Teknik Famili 100 dapat digunakan sebagai alternatif dalam proses pembelajaran pada peserta didik kelas IX MTs Negeri Gowa. Teknik analisis data menggunakan analisis deskriptif dan inferensial. Berdasarkan analisis deskriptif untuk minat belajar peserta didik terhadap model pembelajaran TGT menunjukkan rata-rata skor minat belajar dikelas eksperimen dan kelas kontrol setelah penelitian sebesar 79,33 dan 73,88 atau berada pada kategori tinggi. Berdasarkan hasil uji normalitas data minat belajar diperoleh nilai signifikan Sig $<0,05$, sehingga dapat disimpulkan bahwa data minat belajar peserta didik tidak berdistribusi normal. Hasil uji Mann Whitney-U untuk minat belajar diperoleh nilai signifikannya 0,000 <0,05, sehingga dapat disimpulkan bahwa minat belajar antara peserta didik kelas IX MTs Negeri Gowa yang mendapatkan pembelajaran dengan menggunakan Model Pembelajaran Koopeatif tipe TGT dengan Teknik Famili 100 lebih tinggi daripada yang menggunakan model pembelajaran konvensional.
\end{abstract}

Kata kunci: Model pembelajaran TGT, Minat Belajar.

\section{Pendahuluan}

Menurut Agus Suprijono (2010: 46) Model pembelajaran merupakan landasan praktik pembelajaran hasil penurunan teori psikologi pendidikan dan teori belajar yang dirancang berdasarkan analisis terhadap implementasi kurikulum dan implikasinya pada tingkat operasional di kelas. Model pembelajaran dapat didefinisikan sebagai kerangka konseptual yang melukiskan prosedur sistematis dalam mengorganisasikan pengalaman belajar untuk mencapai tujuan belajar.

Menurut Slavin (2005: 4) Pembelajaran kooperatif bukanlah gagasan baru dalam dunia pendidikan, tetapi sebelum masa belakangan ini, metode hanya digunakan oleh beberapa guru untuk tujua-tujuan tertentu, seperti tugas-tugas atau laporan kelompok tertentu. Namun demikian, penelitian selama dua puluh tahun terakhir ini telah mengidentifikasi metode pembelajaran kooperatif yang dapat diguankan secara efektif pada setiap tingkatan kelas dan untuk mengajarkan berbagai macam pelajaran. Mulai dari matematika, membaca, menulis, sampai pada ilmu pengetahuan ilmiah, mulai dari kemapuan dasar sampai pemecahan masalah-masalah yang kompleks. Lebih dari pada itu, pembelajaran kooperatif juga dapat digunakan sebagai cara utama dalam mengatur kelas untuk pengajaran.

Pembelajaran dengan cooperative learning dapat ditandai oleh fitur-fitur berkut ini: 1) Siswa bekerja dalam tim untuk mencapai tujuan bersama; 2) Tim itu terdiri atas siswa-siswa yang berprestasi rendah, sedang dan tinggi; 3) Bilamana mungkin, tim-tim itu terdiri atas campuran ras, budaya, dan gender; 4) Sistem rewardnya berorientasi kelompok maupun individu (Richard, 2008: 5).

Minat dalam kamus besar Bahasa Indonesia adalah kecenderungan hati yang tinggi terhadap sesuatu; gairah; keinginan. Hilgrad dalam Slameto 2003 menyatakan "interest is persiting tendency to pay attention to and enjoy some activity or content". Minat adalah kecenderungan yang tetap untuk memperhatikan dan mengenang beberapa kegiatan. Kegiata termasuk belajar yang diminati anak akan diperhatikan terus-menerus yang disertai rasa senang. Oleh karena itu, ada juga yang mengartikan minat dengan perasaan 
senang atau tidak senang terhadap suatu objek (Marjani, 2012: 8).

Berdasarkan observasi di MTs Negeri BalangBalang Gowa pada kelas IX ditemukan adanya permasalahan yang berhubungan dengan peserta didik sebagai subyek dalam proses pembelajaran. Masalah tersebut berkaitan dengan minat belajar peserta didik yang masih sangat rendah terutama dalam pelajaran fisika. Di sekolah ini, guru lebih sering menggunakan metode ceramah dalam proses pembelajaran. Penyampaian materi pada awal pembelajaran kurang membuat peserta didik untuk lebih bersemangat mengeluarkan ide-ide kreatifnya dan guru masih mendominasi kelas. Akibatnya, pembelajaran tidak lebih dari penyampain informasi secara verbal kepada peserta didik sehingga proses pembelajaran menjadi kurang efektif. Jika guru melontarkan pertanyaan kepada peserta didik, hanya beberapa peserta didik yang berani dan mau menjawab. Permasalahan lain tampak ketika guru sedang menjelaskan materi dimana sebagian besar peserta didik tidak memperhatikan penjelasan dari guru, beberapa peserta didik tampak mengantuk, melamun, sibuk keluar masuk ruangan ada pula yang asyik mengobrol dengan teman sebangkunya, ini memperlihatkan bahwa ketertarikan atau minat terhadap pelajaran fisika masih sangat kurang.

Melihat kenyataan tersebut, maka guru dituntut untuk mengembangkan suatu model pembelajaran fisika yang lebih inovatif. Pemilihan model pembelajaran yang tepat akan mampu meningkatkan minat belajar peserta didik sehingga mereka tidak akan mengalami kesulitan karena merasa senang terhadap pelajaran yang diajarkan. Salah satu upaya untuk meningkatkan minat belajar peserta didik adalah dengan menerapkan suatu model pembelajaran yang menyenangkan dan memungkinkan semua peserta didik dapat berpartisipasi selama pembelajaran yakni melalui penggunaan model pembelajaran kooperatif tipe Teams-Games-Tournaments (TGT). Teams-Games-Tournament (TGT) merupakan salah satu strategi pembelajaran kooperatif yang dikembangkan oleh Slavin. untuk membantu peserta didik mereview dan menguasai materi pelajaran. Slavin menemukan bahwa TGT berhasil meningkatkan skill-skill dasar, pencapaian, interaksi positif antar peserta didik, harga diri, dan sikap penerimaan pada peserta didik-peserta didik lain yang berbeda (Miftahul, 2015: 196 -197)

Secara umum TGT merupakan pembelajaran yang dilaksanakan di dalam kelas dengan membentuk kelompok-kelompok kecil, guru memberikan permainan akademik dan guru mengadakan turnamen/kompetisi antar kelompok, agar lebih menyenangkan turnamen antar kelompok ini dikemas dengan teknik kuis Famili 100. Bentuk turnamen ini akan mengikuti langkah-langkah dari kuis famili 100, dimana dua kelompok akan berusaha untuk menebak jawaban dari soal-soal yang telah disediakan, setiap soal memiliki poin yang berbeda tergantung tingkat kesukarannya.

Berdasarkan uraian di atas maka peneliti ingin menguji coba untuk menerapakan model pembelajaran tipe Teams-Games-Tournament (TGT) dengan teknik famili 100 pada peserta didik kelas IX dalam proses pembelajaran dengan harapan model pembelajaran kooperatif tipe TGT dengan teknik famili 100 ini dapat menumbuhkan minat belajar fisika peserta didik. Sehingga peneliti mengusulkan penelitian dengan judul "Pengaruh Penggunaan Model Pembelajaran Kooperatif Tipe Teams-Games-Tournament (TGT) dengan Teknik Famili 100 terhadap Minat belajar Fisika Peserta didik Kelas IX di MTs Negeri Gowa", dengan tujuan 1) Untuk mengetahui gambaran minat belajar fisika peserta didik yang diajar menggunakan Model Pembelajaran Tipe Teams-Games-Tournament (TGT) dengan teknik Famili 100; 2) Untuk mengetahui gambaran minat belajar fisika peserta didik yang diajar menggunakan Model Pembelajaran Konvensional; 3)Untuk mengetahui perbedaan minat belajar peserta didik yang diajar menggunakan Model Pembelajaran Kooperatif Tipe Teams-Games-Tournament (TGT) dengan Teknik Famili 100 dengan peserta didik yang diajar dengan Model pembelajaran konvensional.

Hasil dari penelitian ini diharapkan dapat memberikan manfaat: 1) Bagi guru, dapat dijadikan acuan dalam menentukan metode dan model pembelajaran yang inovatif untuk memperbaiki kualitas pembelajaran agar peserta didik tidak merasa bosan selama proses pembelajaran sehingga dapat meningkatkan minat belajar peserta didik; 2) Bagi peserta didik, 
peserta didik mendapatkan pengalaman baru dalam pembelajaran fisika setelah diterapkannya model pembelajaran tipe TGT dengan Teknik Famili 100 pada materi Kemagnetan sehingga diharapkan dapat meningkatkan minat belajar peserta didik; 3) Bagi peneliti, dapat menambah wawasan dan pengalaman serta terampil dalam memilih dan melaksanakan model pembelajaran yang efektif bagi peserta didik.

\section{Metode Penelitian}

Dalam penelitian ini digunakan jenis penelitian Pra-Eksperimen. Dengan desain penelitian adalah "The Static Group Comparison". Di dalam desain ini, dua kelompok dipilih, satu diantaranya menerima perlakuan dan satu yang lain tidak menerima perlakuan. Suatu skor postes ditentukan untuk mengukur perbedaan setelah perlakuan anatara kedua kelompok.

Populasi dalam penelitian ini adalah semua siswa kelas IX MTs Negeri GOWA yang terdaftar pada tahun ajaran 2016/2017 yang terdiri dari enam (6) kelas dengan jumlah siswa 245 orang. Metode pengambilan sampel dilakukan dengan menggunakan teknik Simple Random Sampling. Teknik ini digunakan karena anggota populasi pada penelitian dianggap homogen selain itu, jumlah populasi tidak terlalu besar yakni 245 orang, maka sampel yang diambil dengan menggunakan teknik Simple Random Sampling ini yaitu kelas IX-5 dan IX-6 MTs Negeri GOWA.

Langkah-langkah yang dilakukan dalam penelitian ini adalah: 1) Tahap persiapan yang meliputi kegiatan: (a) Menentukan lokasi penelitian, (b) mengurus surat izin penelitian, (c) Melakukan observasi lapangan sebelum melakukan penelitian, (d) Menentukan kelas sampel penelitian, waktu pelaksanaan dan materi yang akan diajarkan saat penelitian, (e) Menyusun perangkat pembelajaran dan instrumen penelitian, yaitu rancangan pengajaran dengan TeamsGames-Tournament (TGT) dengan Teknik Famili 100. Perangkat pembelajaran yang digunakan pada penelitian ini meliputi Rencana Pelaksanaan Pembelajaran (RPP) dan juga instrumen penelitian berupa lembar observasi dan Angket minat belajar, (f) Melakukan Validasi, sebelum digunakan dalam penelitian perangkat pembelajaran dan instrument divalidasi oleh ahli dan praktisi. Tujuannya adalah untuk mendapatkan kebenaran isi angket minat belajar. Perangkat pembelajaran, angket minat belajar divalidasi oleh seorang ahli (dosen), (g) Revisi instrument. 2) Tahap pelaksanaan, peneliti menggunakan dua kelas. Kelas IX-5 sebagai kelas eksperimen dengan pembelajaran TGT dengan Teknik Famili 100, dan kelas IX-6 sebagai kelas control dengan pembelajaran secara konvensional. Dalam pelaksanaan pembelajaran TGT dengan teknik Famili 100 terdiri dari dua babak permainan, yakni babak Top Survey dan Babak Jackpot dengan langkah-langkah sebagai berikut: (a) Guru membagi siswa dalam beberapa kelompok yang terdiri dari 5-6 siswa secara heterogen, (b) Setiap kelompok diberi nomor undian, (c) Setiap satu perwakilan kelompok diminta mencabut kartu undian, bagi perwakilan yang mendapat nomor urut I dan II maka kelompoknyalah yang bertanding terlebih dulu dan yang lain menyaksikan, dan menunggu giliran untuk bertanding, (d) Salah satu pemain dari masing-masing perwakilan kelompok yang bertanding akan maju ke depan untuk saling berebut menjawab pertanyaan yang telah disediakan dengan poin yang telah ditentukan, (e) Jika pemain dalam babak ini menjawab dengan salah, maka pertanyaan akan dilempar kepada lawan, (f) Kelompok yang pemainnya menjawab pertanyaan Top Survey keempat dengan benar akan mendapat penambahan bonus. (misal, nilai awal sampai pada peserta ketiga adalah 10 poin maka akan dilipat gandakan menjadi 20 poin). Selanjutnya masuk ke babak II (babak jackpot): (a) Dari babak Top Survey, akan dipilih dua kelompok yang memiliki poin tertinggi yang akan dipertandingkan pada babak selanjutnya yaitu babak Jackpot, (b) Salah satu pemain dari masing-masing kelompok akan maju ke depan dan menjawab pertanyaan yang telah disediakan dengan beberapa jawaban teratas yang tersedia di papan, (c) Tim yang memberikan jawaban yang memiliki posisi lebih tinggi (yang diurutkan berdasarkan poin) atau menjawab jawaban dengan posisi tertinggi di dalam barisan jawaban dapat mengendalikan permainan dengan memilih untuk memainkan pertanyaan atau melempar pertanyaan kepada kelompok lawan, (d) Kelompok yang bermain secara bergilir pertanyaan yang sama dan mencoba menjawab seluruh jawaban teratas yang belum ditebak, (e) Pada akhir babak kelompok 
yang memiliki poin tertinggi akan keluar menjadi pemenang dan berhak mendapat Reward. 3) Tahap Evaluasi yaitu dengan memberikan kuesioner minat belajar fisika pada kelas eksperimen dan kelas kontrol untuk mengetahui tingkat minat belajar fisika siswa kelas IX MTs Negeri Gowa.

Instrumen yang digunakan untuk mengumpulkan data dalam penelitian ini adalah sebagai berikut: 1) Angket (Kuesioner), menurut Suharsimi (2013: 194) angket adalah sejumlah pertanyaan tertulis yang digunakan untuk memperoleh informasi dari responden dalam arti laporan tentang pribadinya atau hal-hal yang ia ketahui. 2) Lembar observasi, Menurut Margono dalam Nurul (2009:173) lembar observasi diartikan sebagai pengamatan dan pencatatan ssecara sistematis terhadap gejala yang tampak pada objek penlelitian; 3) Recana Pelaksanaan pembelajaran, merupakan skenario pelaksanaan proses pembelajaran dalam kelas yang diatur secara sistematis, dimana RPP yang dibuat oleh penulis adalah RPP yang berbasis kurikulum 2013 yang disesuaikan dengan materi kemagnetan.

Penelitian ini bertujuan untuk menguji komparatif dua sampel independen yang datanya berbentuk ordinal maka peneliti menggunakan Uji MannWhitney $U$. Uji $U$ ini tidak memerlukan asumsi distribusi normal dan homogenitas variance, yang diperlukan adalah data kontinu dan data yang mempunyai skala ordinal. Prosedur dalam menguji dengan uji Mann-Whitney $U$.

\section{Hasil dan Pembahasan}

\section{Kelas Eksperimen}

Berdasarkan hasil yang diperoleh dari instrumen angket dengan jumlah pertanyaan sebanyak 34 nomor pada peserta didik kelas IX-5 MTs Negeri Gowa setelah diajar dengan model Pembelajaran Kooperatif Tipe Teams Games Tournament (TGT) dengan Teknik Famili 100. Maka diperoleh data minat belajar fisika yang disajikan dalam bentuk tabel berikut:

Tabel 1. Data minat belajar fisika peserta didik kelas IX-5 MTs Negeri Gowa setelah diterapkan model pembelajaran Kooperatif Tipe Teams Games Tournament (TGT) dengan Teknik Famili 100

\begin{tabular}{cc} 
Parameter & Nilai \\
\hline Nilai Maksimum & 93 \\
\hline Nilai Minimum & 63 \\
\hline Rata-rata & 79,32 \\
\hline Standar Deviasi & 6,49 \\
\hline Varians & 42,21 \\
\hline Koefisien Varians & $8,18 \%$
\end{tabular}

Berdasarkan data yang diperoleh dari hasil analisis deskriptif, maka minat belajar fisika peserta didik kelas IX-5 MTs Negeri Gowa pada kelas eksperimen dikategorisasikan dengan hasil yang ditunjukkan pada tabel 2 berikut:

Tabel 2. Kategorisasi Minat Belajar Fisika

\begin{tabular}{ccccl} 
No & $\begin{array}{c}\text { Rentang } \\
\text { Nilai }\end{array}$ & Frekuensi & $\begin{array}{c}\text { Perse } \\
\text { ntase } \\
(\%)\end{array}$ & Kategori \\
\hline 1 & $25-39$ & 0 & 0 & $\begin{array}{l}\text { Sangat } \\
\text { Rendah }\end{array}$ \\
\hline 2 & $40-54$ & 0 & 0 & Rendah \\
\hline 3 & $55-69$ & 3 & 8,82 & Sedang \\
\hline 4 & $70-84$ & 24 & 70,56 & Tinggi \\
\hline 5 & $85-100$ & 7 & 20,58 & $\begin{array}{l}\text { Sangat } \\
\text { Tinggi }\end{array}$ \\
\hline \multicolumn{2}{c}{ Jumlah } & 34 & $100 \%$ &
\end{tabular}

Untuk menghitung persentase minat belajar fisika yang diajar dengan model pembelajaran Kooperatif Tipe Teams Games Tournament (TGT) dengan Teknik Famili 100 dilakukan pengkategorisasian minat belajar, terdapat 24 peserta didik dengan persentase 70,56\% minat belajar peserta didik berada pada kategori tinggi, terdapat 7 peserta didik dengan persentase 20,58 $\%$ minat belajar peserta didik pada kategori sangat tinggi, dan hanya terdapat 3 orang peserta didik dengan persentase $8,82 \%$ berada pada kategori sedang. Hal ini terlihat pada saat proses pembelajaran berlangsung dimana peserta didik tersebut memang lebih menampakkan keaktifan dan ketertarikannya, seperti lebih serius memperhatikan penjelasan peneliti dengan tetap mencatat hal-hal penting yang disampaikan, peserta didik terlihat lebih aktif berinteraksi dan berkomunikasi secara langsung kepada sesama temannya khususnya anggota kelompoknya seperti bertanya, menjelaskan, mengemukakan pendapat dan lain sebagainya. Selain itu, juga terlihat ketertarikan peserta didik terhadap model pembelajaran TGT ini dengan senantiasa mengikuti pembelajaran hingga jam pelajaran 
berakhir. Dari aspek perasaan terlihat peserta didik lebih bergembira dikarenakan proses pembelajaran yang dikemas dengan Turnamen yang begitu familiar yakni kuis Famili 100 sehingga membawa peserta didik dalam game yang menyenangkan. Dengan demikian bahwa minat belajar peserta didik pada kelompok eksperimen dikatakan sangat baik.

Beberapa hasil penelitian juga mengemukakan bahwa penggunaan model pembelajaran Teams Games Tournament (TGT) dapat berpengaruh untuk meningkatkan minat belajar peserta didik. Salah satunya adalah hasil penelitian Aningtyas dalam skripsi Nur Hafizah (2013: 7) yang menyatakan bahwa TGT salah satu model pembelajaran yang menarik dan efektif karena setiap peserta didik mempunyai kesempatan yang samauntuk menjadi yang terbaik di meja turnamennya. Adanya keinginan peserta didik untuk memahami materi mendorong para peserta didik untuk berinteraksi dan berkomunikasi secara langsung kepada sesama temannya khususnya kepada anggota kelompoknya seperti bertanya, menjelaskan, mengemukakan pendapat, dan lain sebagainya sehingga peserta didik tidak hanya mendapatkan sumber belajar dari guru atau bahan ajar tetapi juga dari temannya sendiri.

Dari uraian data minat belajar diatas, bahwa ratarata tingkat minat belajar peserta didik berada pada kategori tinggi dengan persentase tinggi juga, sehigga menunjukkan bahwa model pembelajaran Kooperatif Tipe Teams Games Tournament (TGT) dengan Teknik Famili 100 dapat memberikan pengaruh positif terhadap minat belajar peserta didik. Hal tersebut seperti yang dikemukakan Sumarni dikutip dari Hafizah (2013: 2) bahwa kelebihan dari pembelajaran TGT yakni keterlibatan peserta didik dalam belajar tinggi, peserta didik menjadi bersemangat dalam belajar, pengetahuan yang diperoleh peserta didik bukan semata-mata dari guru tetapi melalui konstruksi sendiri oleh peserta didik, dan dapat menumbuhkan sikap positif dalam diri peserta didik seperti kerja sama, toleransi, bisa menerima pendapat orang lain, dan lain-lain.

\section{Kelas Kontrol}

Berdasarkan hasil angket minat belajar fisika peserta didik kelas IX-6 MTs Negeri Gowa (Kelas Kontrol) setelah diajar dengan model pembelajaran konvesional. Maka diperoleh data minat belajar fisika yang disajikan dalam bentuk tabel distribusi frekuensi pada tabel 3 berikut:

Tabel 3. Data minat belajar peserta didik kelas IX-6 MTs Negeri Gowa yang diajar dengan model pembelajaran konvensional

\begin{tabular}{cc} 
Parameter & Nilai \\
\hline Nilai Maksimum & 91 \\
\hline Nilai Minimum & 68 \\
\hline Rata-rata & 73,88 \\
\hline Standar Deviasi & 7,38 \\
\hline Varians & 54,47 \\
\hline Koefisien Varians & $9,98 \%$
\end{tabular}

Berdasarkan data yang diperoleh dari hasil analisis deskriptif, maka minat belajar fisika peserta didik MTs Negeri Gowa pada kelas komtrol dikategorisasikan dengan hasil yang ditunjukkan pada tabel 4 berikut.

Tabel 4. Kategorisasi Minat Belajar Fisika (Kelas Kontrol)

\begin{tabular}{|c|c|c|c|c|}
\hline No & $\begin{array}{l}\text { Rentang } \\
\text { Nilai }\end{array}$ & $\begin{array}{c}\text { Freku } \\
\text { ensi }\end{array}$ & $\begin{array}{c}\text { Persen } \\
\text { tase } \\
(\%)\end{array}$ & Kategori \\
\hline 1 & $25-39$ & 0 & 0 & $\begin{array}{l}\text { Sangat } \\
\text { Rendah }\end{array}$ \\
\hline 2 & $40-54$ & 0 & 0 & Rendah \\
\hline 3 & $55-69$ & 1 & 2.94 & Sedang \\
\hline 4 & $70-84$ & 27 & 79.42 & Tinggi \\
\hline 5 & $85-100$ & 6 & 17.64 & $\begin{array}{l}\text { Sangat } \\
\text { Tinggi }\end{array}$ \\
\hline
\end{tabular}

Untuk menghitung persentase minat belajar fisika yang diajar dengan model pembelajaran konvensional dilakukan pengkategorisasian minat belajar, terdapat 27 peserta didik dengan persentase 79,42 \% minat belajar peserta didik berada pada kategori tinggi. Dan terdapat 6 peserta didik dengan persentase 17,64 \% minat belajar peserta didik pada kategori sangat tinggi, hal ini terlihat selama pembelajaran berlangsung peneliti dapat melihat adanya beberapa perubahan sikap pada diri peserta didik di kelas kontrol ini, meskipun perubahan sikap ini tidak sekompleks perubahan sikap yang terjadi pada diri peserta didik di kelas eksperimen. Perubahan sikap tersebut misalnya peserta didik mulai bertanggung jawab terhadap tugas yang diberikan. Walaupun demikian masih ada anggota kelompok yang tidak 
melaksanakan tanggung jawabnya dengan baik, misalnya mereka menyerahkan tugas yang menjadi tanggung jawabnya kepada teman yang dianggap menguasai materi. Terlihat peserta didik juga memperhatikan dan mencatat materi yang diajarkan. Kemampuan peserta didik bertanya juga sudah tampak. Meskipun belum semua peserta didik memiliki keberanian untuk bertanya. Begitu pula dengan kemampuan peserta didik menjawab pertanyaan peneliti. Ketika peneliti menyampaikan materi ajar, peneliti selalu melontarkan pertanyaan-pertanyaan guna mengetahui pendapat peserta didik mengenai materi ajar, sehingga dalam hal ini tidak terdapat dominasi peneliti dalam mentransfer pengetahuan kepada peserta didik. Dengan demikian bahwa minat belajar peserta didik pada kelompok kontrol juga dapat dikatakan sangat baik.

Melihat uraian di atas, bahwa rata-rata tingkat minat belajar peserta didik berada pada kategori tinggi dengan persentase tinggi juga, sehingga menunjukkan bahwa pembelajaran konvensional juga memberi pengaruh positif terhadap minat belajar peserta didik berdasarkan tes angket yang diberikan.

Hal tersebut sejalan dengan ungkapan Ahmad dalam skripsi Jamil (2016: 77-78) yang menyatakan bahwa dengan menggunakan model pembelajaran konvensional dapat membangun keterampilan, kemampuan berfikir secara kritis dan kemampuan mencari jawaban sendiri yang berkaitan dengan materi fisika yang telah dipelajarinya, dan meningkatkan semangat dan minat belajar serta dapat dikatakan bahwa model pembelajaran ini juga dapat memberikan pengaruh positif terhadap minat belajar peserta didik.

Berdasarkan hasil analisis deskriptif, pada kelas yang diajar dengan model TGT dengan teknik famili 100 menunjukkan bahwa minat belajar fisika peserta didik rata-rata berada pada kategori tinggi. Begitupun pada kelas yang diajar dengan model pembelajaran secara konvensional, yang menunjukkan bahwa rata-rata minat belajar fisika peserta didik berada pada kategori tinggi. Tetapi minat belajar fisika peserta didik yang diajar dengan model TGT dengan teknik famili 100 menunjukkan minat belajar peserta didik pada kategori sangat tinggi lebih besar dari peserta didik yang diajar dengan model pembelajaran secara konvensional. Selain itu, nilai rata-rata (mean) untuk masing-masing kelas tersebut yang ditunjukkan dari hasil analisis deskriptif juga memiliki.

Hasil perhitungan analisis statistik Uji MannWhitney $U$ menggunakan program IBM SPSS Versi 20 for Windows dimana diperoleh nilai signifikan sebesar 0,000 yang kurang dari alpha $(0,05)$. Maka pengambilan kesimpulan hipotesis yaitu Ha diterima dan hipotesis Ho ditolak. Hasil uji Mann-Whitney $U$ tersebut menunjukkan bahwa terdapat perbedaan yang signifikan antara nilai minat belajar peserta didik antara kelas yang menggunakan model pembelajaran Teams Games Tournament (TGT) dengan menggunakan pembelajaran konvensional.

Sesuai dengan penelitian Atika (2013: 108-109) dimana minat belajar peserta didik yang menggunakan model pembelajaran Teams Games Tournament (TGT) diketahui lebih baik dari pada minat belajar peserta didik yang menggunakan model pembelajaran konvensional. Terlihat dari nilai minat belajar yang diperoleh peserta didik di kelas eksperimen, rata-ratanya sebesar 88,12 dan rata-rata nilai minat belajar kelas kontrol 70,85. Nilai minat belajar di kelas eksperimen lebih tinggi jika dibandingkan yang diperoleh kelas kontrol.

Berdasarkan hasil uji hipotesis yang dijelaskan di atas, dapat disimpulkan bahwa model pembelajaran Kooperatif tipe Teams Games Tournament (TGT) berpengaruh terhadap minat belajar peserta didik, karena kedua kelas memiliki perbedaan minat belajar yang signifikan antara kelas yang diajar dengan model TGT dengan Teknik Famili 100 (kelas IX-5) dan yang diajar dengan model pembelajaran secara konvensional (kelas IX-6).

\section{Kesimpulan}

1. Persentase nilai Minat belajar peserta didik yang diajar dengan model pembelajaran Kooperatif Tipe Teams Games Tournament (TGT) dengan Teknik Famili 100 adalah 70,56 \% berada pada kategori tinggi dan $20,58 \%$ berada pada kategori sangat tinggi. 
2. Persentase nilai minat belajar peserta didik yang diajar dengan model pembelajaran Konvensional adalah $79,42 \%$ berada pada kategori tinggi dan $17,64 \%$ berada pada kategori sangat tinggi.

3. Perbedaan minat belajar kelas eksperimen dan kelas kontrol dapat dilihat pada analisis uji Z dimana nilai signifikan yang diperoleh sebesar 0,000 yang kurang dari nilai alpha $(0,05)$. Untuk kriteria pengujian, Ho ditolak, Ha diterima jika $\mu 1$ $<\mu 2$, dan Ho diterima, Ha ditolak jika $\mu 1 \geq \mu 2$. Karena $0,000<0,05$ maka Ha diterima atau dapat disimpulkan bahwa terdapat perbedaan minat belajar yang signifikan anatara kelas yang diajar dengan model pembelajaran Kooperatif Tipe Teams Games Tournament (TGT) dengan Teknik Famili 100 dengan model pembelajaran Konvensional pada kelas IX MTs Negeri Gowa.

\section{Implikasi}

Berdasarkan hasil penelitian ini perlu dikemukakan implikasi sebagai berikut :

1. Guna penelitian selanjutnya, dengan menggunakan model pembelajaran Kooperatif Tipe Temas Games Tournament (TGT) dengan Teknik Famili 100 maka dapat dilakukan dengan jenis penelitian yang berbeda dari sebelumnya seperti Quasi Experiment atau True Experiment.

2. Sampel penelitian yang digunakan peneliti adalah kelas IX MTs Negeri Gowa, dimana jika penelitian yang selanjutnya dilakukan dengan sampel yang berbeda maka diperlukan kontrol yang maksimal terhadap peserta didik dan pengaturan waktu yang baik, agar kegiatan pembelajaran dapat berjalan lebih kondusif.

\section{Daftar Pustaka}

Alwi, Marjani. 2012. Mengapa Anak Malas Belajar (Solusi Belajar Efektif dan Menyenangkan). Makassar: Alauddin University Press.

Arends, Richard I. 2005. Learning To Teach: Belajar untuk Mengajar. Yogyakarta: Pustaka Media.
Arikunto, Suharsimi. 2006. Prosedur Penelitian Suatu Pendekatan Praktik. Edisi Revisi. Jakarta: PT. Rineka Cipta.

Emilia, Atika. 2013. Keefektifan Model Pembelajaran TGT Terhadap Minat Dan Hasil Belajar Struktur Bumi Pada Siswa Kelas V Sekolah Dasar Negeri Marga Ayu 01 Kabupaten Tega. Semarang: UNNES Press.

Huda, Miftahul. 2015. Coopertive Learning. Yogyakarta: Pustaka Pelajar. Cet. X.

Nur Hafizah dkk. 2013. Pengaruh Penggunaan Model Pembelajaran Teams Games Tournament (TGT) Terhadap Minat Belajar Siswa Pada Mata Pelajaran Geografi di MA Al-Islah SendangagungPaciran-Lamongan. Malang: Universitas Negeri Malang Press.

Rahmat, Jamil. 2016. Pengaruh Model Pembelajaran Note-Taking Pairs Terhadap Minat Belajar Dan Hasil Belajar Siswa Kelas VIII SMP Negeri 2 Kab. Bantaeng. Makassar: UINAM Press.

Slavin, Robert E. 2005. Cooperatif Learning: Theory, Research and Practice. Bandung: Nusa Media.

Suprijono, Agus. 2009. Cooperatif Learning. Yogyakarta: Pustaka Pelajar.

Zuriah, Nurul. 2009. Metodologi Penelitian Social dan Pendidikan. Jakarta: Bumi Aksara. 